\title{
ANALISIS PENINGKATAN DAYA MINAT DAN MOTIVASI BELAJAR SISWA MENGGUNAKAN DELTA MULTIMEDIA EDUTAINMENT SEBAGAI MEDIA PENUNJANG PEMBELAJARAN
}

\author{
Dina Fitria Murad ${ }^{1}$, Willy Johan Widjaja Saputra ${ }^{2}$ \\ ${ }^{1}$ Sistem Informasi, Binus Online Learning, Universitas Bina Nusantara, Jakarta, Indonesia \\ ${ }^{2}$ Sistem Informasi, Binus Online Learning, Universitas Bina Nusantara, Jakarta, Indonesia \\ 1dmurad@binus.edu
}

\begin{abstract}
Professor Toshiko Kinosita stated that Indonesia's human resources are still very weak to support industrial and economic development. The reason is because the government has never put education as the most important priority. Education is not placed as the most important priority because the people of Indonesia, ranging from the layman to politicians and government officials, are only pursuing money pursuits to enrich themselves and never think long. The opinion of the Japanese Waseda University Professor is very interesting to study considering that the Indonesian government is now starting to look at education as a long-term investment, after all this time education has been neglected. One indicator is that the MPR has agreed to prioritize the education budget of at least $20 \%$ of the APBN or APBD. This step is an initial awareness of the importance of education as a long-term investment. This study measures the extent to which the correlation and impact of the use of Information Technology in the teaching and learning process on student achievement in SMA Negeri 8 Tangerang. This research also modeled a learning media with Multimedia method which we named Delta Multimedia Edutainment (DME) which is a local web-based learning media school. The target to be achieved is an increase in interest and student achievement in SMA Negeri 8 Tangerang. The results of this study are useful for schools in improving school performance and maintaining the quality of graduates.
\end{abstract}

Keywords: Delta multimedia edutainment, modern education, interest in learning, learning motivation, student achievement, information technology

\begin{abstract}
ABSTRAK
Profesor Toshiko Kinosita mengemukakan bahwa sumber daya manusia Indonesia masih sangat lemah untuk mendukung perkembangan industri dan ekonomi. Penyebabnya karena pemerintah selama ini tidak pernah menempatkan pendidikan sebagai prioritas terpenting. Tidak ditempatkannya pendidikan sebagai prioritas terpenting karena masyarakat Indonesia, mulai dari yang awam hingga politisi dan pejabat pemerintah, hanya berorientasi mengejar uang untuk memperkaya diri sendiri dan tidak pernah berfikir panjang. Pendapat Guru Besar Universitas Waseda Jepang tersebut sangat menarik untuk dikaji mengingat saat ini pemerintah Indonesia mulai melirik pendidikan sebagai investasi jangka panjang, setelah selama ini pendidikan terabaikan. Salah satu indikatornya adalah telah disetujuinya oleh MPR untuk memprioritaskan anggaran pendidikan minimal $20 \%$ dari APBN atau APBD. Langkah ini merupakan awal kesadaran pentingnya pendidikan sebagai investasi jangka panjang. Penelitian ini mengukur sejauh mana korelasi dan dampak pemanfaatan Teknologi Informasi dalam proses belajar mengajar terhadap prestasi belajar siswa di SMA Negeri 8 Tangerang. Penelitian ini juga memodelkan sebuah media pembelajaran dengan metode Multimedia yang kami namakan Delta Multimedia Edutainment (DME) yang merupakan media pembelajaran berbasis web lokal sekolah. Target yang ingin dicapai adalah peningkatan minat dan prestasi belajar siswa di SMA Negeri 8 Kota Tangerang. Hasil penelitian ini bermanfaat bagi sekolah dalam meningkatkan prestasi sekolah dan tetap mempertahankan mutu lulusan.
\end{abstract}

Kata kunci: Delta multimedia edutainment, pendidikan modern, minat belajar, motivasi belajar, prestasi siswa, teknologi informasi. 


\section{PENDAHULUAN}

Perkembangan teknologi informasi dan komunikasi sangat berdampak besar pengaruhnya terhadap dunia pendidikan khususnya dalam proses pembelajaran. Pengaruh perkembangan teknologi informasi dan komunikasi dalam proses pembelajaran adalah pada inovasi pengembangan media pembelajaran yang lebih menarik dan komunikatif. Sehingga dapat memotivasi siswa dalam mengikuti proses pembelajaran, dan berdampak pada hasil belajar yang diperoleh siswa karena siswa dengan mudah dapat menyerap materi yang diajarkan. Serta adanya jaringan internet guru dan siswa dapat memperoleh informaasi dengan cepat serta dapat berbagi informasi menggunakan media sosial. Dengan adanya teknologi maka akses informasi akan semakin cepat dan mudah didapat, hal ini terjadi pada generasi melenial dimana mereka belajar dengan cepat melalui akses informasi yang mudah tersebut. Sayangnya fenomena ini tidak di imbangi dengan kesiapan sekolah dalam mempersiapkan siswa dengan teknologi yang ada dilingkungan sekitarnya. Ketidaksiapan sekolah akan mengakibatkan siswa menjadi tidak kritis dan terpaku dalam metode belajar gaya tradisional lama yang sudah ditinggalkan.

Sekolah harus mengubah proses belajar mengajar dan menggunakan teknologi sebagai alat bantu untuk meningkatkan proses berfikir siswa, dan mempersiapkan siswa dalam bersaing di era globalisasi. Dengan adanya teknologi dalam proses belajar mengajar siswa maka siswa akan lebih kritis, lebih tertarik untuk ingin tahu dan mempercepat proses penyerapan belajar.

Para penganut teori human capital berpendapat bahwa pendidikan adalah sebagai investasi sumber daya manusia yang memberi manfaat moneter ataupun non-moneter. Manfaat non-moneter dari pendidikan adalah diperolehnya kondisi kerja yang lebih baik, kepuasan kerja, efisiensi konsumsi, kepuasan menikmati masa pensiun dan manfaat hidup yang lebih lama karena peningkatan gizi dan kesehatan. Manfaat moneter adalah manfaat ekonomis yaitu berupa tambahan pendapatan seseorang yang telah menyelesaikan tingkat pendidikan tertentu dibandingkan dengan pendapatan lulusan pendidikan dibawahnya.

Secara umum terbukti bahwa semakin berpendidikan seseorang maka tingkat pendapatannya semakin baik. Hal ini dimungkinkan karena orang yang berpendidikan lebih produktif bila dibandingkan dengan yang tidak berpendidikan. Produktivitas seseorang tersebut dikarenakan dimilikinya keterampilan teknis yang diperoleh dari pendidikan. Oleh karena itu salah satu tujuan yang harus dicapai oleh pendidikan adalah mengembangkan keterampilan hidup. Inilah sebenarnya arah kurikulum berbasis kompetensi, pendidikan life skill dan broad based education yang dikembangkan di Indonesia akhir-akhir ini. Di Amerika Serikat (1992) seseorang yang berpendidikan doktor penghasilan rata-rata per tahun sebesar 55 juta dollar, master 40 juta dollar, dan sarjana 33 juta dollar. Sementara itu lulusan pendidikan lanjutan hanya berpanghasilan ratarata 19 juta dollar per tahun. Pada tahun yang sama, struktur ini juga terjadi di Indonesia. Misalnya rata-rata, antara pedesaan dan perkotaan, pendapatan per tahun lulusan universitas 3,5 juta rupiah, akademi 3 juta rupiah, SLTA 1,9 juta rupiah, dan SD hanya 1,1 juta rupiah.

Begitupun dengan SMA Negeri 8 Tangerang yang merupakan salah satu SMA Negeri Unggulan di Kota Tangerang. Sebagai salah satu sekolah terbaik, SMA Negeri 8 selalu bersaing dengan kompetitornya yaitu SMA Negeri 1 dan SMA Negeri 7 yang sama-sama selalu mengukir prestasi terbaik disetiap tahunnya. Hal ini sejalan dengan jumlah lulusan yang diterima di Perguruan Tinggi favorit di Indonesia seperti Universitas Indonesia, Institute Teknologi Bandung, Universitas Padjajaran dan Universitas Gajah Mada. Support dari Dinas Pendidikan Kota Tangerang terhadap sekolah-sekolah unggulan ini sudah cukup bagus namun kendala yang dialami selalu ada pada kemampuan Guru yang sebagian besarnya memiliki background pendidikan non IT. Temuan terhadap beberapa matapelajaran adalah tingginya respon siswa terhadap penggunaan IT oleh guru, baik dalam bentuk aplikasi sederhana menggunakan Microsoft Office dan juga aplikasi tertentu yang digunakan sekolah dari hasil kerjasama dengan beberapa vendor.

Berbagai model pembelajaran dikembangkan untuk memaksimalkan fungsi pembelajaran disemua lini jenjang pendidikan. SMA Negeri 8 Tangerang merupakan salah satu sekolah terbaik di Kota Tangerang. Faktor lingkungan dan kebiasaan peserta didik sangat mempengaruhi pola dan gaya belajar siswa. Hal ini terlihat pada kegiatan ekstra kurikuler serta kebutuhan terhadap penggunaan media lain selain papan tulis. Keberhasilan pembelajaran dengan e-learning sudah 
berhasil dilakukan beberapa institusi, diantaranya adalah e-learning sebagai media untuk segmentasi pengetahuan (Hariri \& Fihri, 2014), e-learning sebagai media keberhasilan studi (Popovici \& Mironov, 2015), e-learning dengan konsep pedagogis (Hubackova, 2014).

Mengadopsi paper tersebut, penelitian ini mengusulkan sebuah model pembelajaran berbasis multimedia edutainment, sebuah e-learning dengan konsep teknologi, mengkombinasikan antara kebutuhan edukasi yang disupport oleh teknologi dan entertainment, yang kami namakan multimedia edutainment dan diharapkan dapat membuktikan tingginya dampak pemanfaatan IT didalam pembelajaran siswa dan Guru bagi minat dan prestasi belajar siswa di SMA Negeri 8 Tangerang.

\section{METODOLOGI PENELITIAN}

Pembelajaran adalah proses interaksi siswa dengan pendidik dan sumber belajar pada suatu lingkungan belajar (UURI No. 20/2003: Sisdiknas Bab I, Pasal 1, ayat 20). Menurut UU Sisdiknas tersebut pembelajaran tidak hanya interaksi antara guru dan siswa tetapi juga melibatkan sumber belajar, jadi siswa tidak hanya memperoleh informasi materi pelajaran dari guru tetapi siswa juga dapat memperoleh dari sumber belajar lain. Dan peran guru disini sebagai fasilitator, mediator yang membuat situasi kondusif untuk terjadinya konstruksi pengetahuan pada diri siswa. Memasuki era teknologi informasi dan komunikasi pada saat ini sangat dirasakan pentingnya pemanfaatan TIK dalam kegiatan pembelajaran untuk meningkatkan kualitas pembelajaran yang diharapkan. Teknologi informasi berkembang sejalan dengan perkembangan teori, komunikasi dan teknologi yang menunjang terhadap praktik kegiatan pembelajaran. Pembelajaran berbasis komputer (CBI), Pembelajaran berbasis web (e-learning), Pembelajaran berbantukan komputer (CAI) adalah bentuk pemanfaatan TIK yang perlu dilaksanakan dalam dunia pendidikan saat ini.

Menurut Arif S. Sadiman Media pembelajaran adalah segala sesuatu yang dapat digunakan untuk menyalurkan pesan dari pengirim ke penerima sehingga dapat merangsang pikiran, perasaan, perhatian dan minat siswa sedemikian rupa sehingga proses belajar terjadi (Arif Sadiman, 2009 : 7).

Perkembangan teknologi informasi dan komunikasi sangat mempengaruhi perkembamgan media pembelajaran, menjadi lebih menarik dengan menggabungkan unsur grafis, audio, video dan animasi atau yang sering disebut dengan multimedia. Komputer adalah alat elektronik yang termasuk kategori multimedia karena komputer menurut Arsyad mampu melibatkan berbagai indera dan organ tubuh, seperti telinga ( audio ), mata ( visual), dan tangan ( kinetik ), yang dengan perlibatan ini dimungkinkan informasi atau pesannya mudah dimengerti (Yudhi Munadi, 2010:148). Dengan menggunakan komputer dapat mengembangkan media pembelajaran yang menarik seperti multimedia presentasi, pembuatan video dan audio pembelajaran.

Dengan adanya komputer kita dapat mengembangkan sebuah media pembelajaran yang menarik, yaitu dengan menggabungkan gambar, video, audio dan animasi menjadi satu media multibahasa atau multimedia yang bisa mencakup indera pendengaran dan penglihatan sehingga daya imajinasi, kreativitas, fantasi dan emosi peserta didik berkembang ke arah yang lebih baik. Jadi multimedia pembelajaran adalah media yang mampu melibatkan banyak indera dan organ tubuh selama proses pembelajaran berlangsung (Yudhi Munadi, 2010: 148).

Beberapa bentuk penggunaan multimedia berbasis komputer yang dapat digunakan dalam proses pembelajaran meliputi :

1. Multimedia presentasi

2. Pembelajaran Berbasis Komputer (CD Multimedia Interaktif)

3. Video Pembelajaran

4. E- Learning

Khusus untuk poin 5 diketahui e-learning memiliki banyak manfaat bagi pembelajaran siswa. Diantaranya adalah mengkombinasikan kebutuhan pembelajaran secara konvensional dengan pemanfaatan IT. Ada 3 (tiga) fungsi pembelajaran elektronik terhadap kegiatan pembelajaran di dalam kelas (classroom instruction), yaitu sebagai suplemen yang sifatnya pilihan/opsional, pelengkap (komplemen), atau pengganti (substitusi) (Siahaan, 2002) seperti terilhat pada gambar.1 


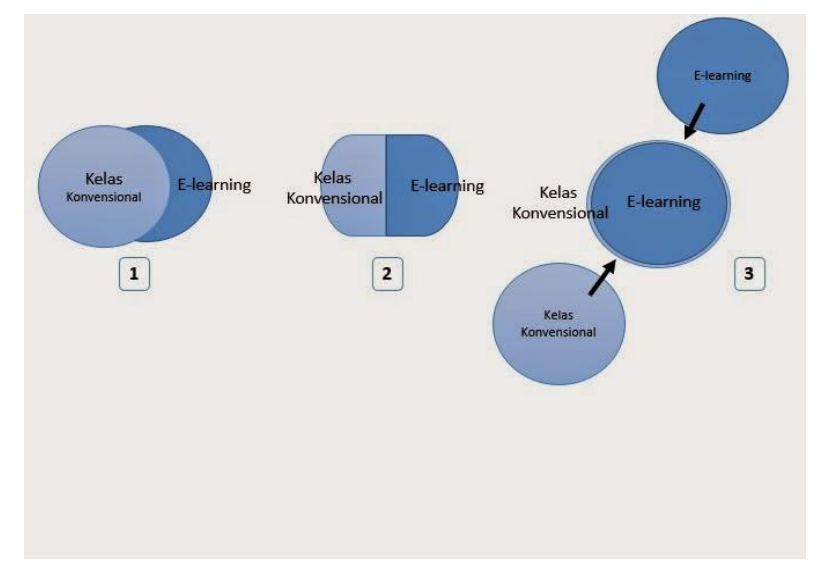

Gambar 1. Fungsi pembelajaran

\section{HASIL DAN PEMBAHASAN}

\subsection{Tujuan Penelitian}

Kedepannya, diharapkan setelah system ini diimplementasikan dengan baik tentu saja perlu penyesuaian terhadap kebutuhan user dan pengguna lainnya seperti guru dan siswa. Secara professional sekolah akan memberikan support dalam bentuk penyediaan fasilitas, hingga akhirnya akan diinformasikan kepada para orangtua tentang keberhasilan sekolah dalam mempersiapkan kebutuhan siswa. Dengan tujuan untuk meningkatkan prestasi siswa dan juga sekolah.

\subsection{Benefits of Resea Hasil yang diharapkan}

Dengan berbagai kepentingan dan kebutuhan terhadap penyesuaian system yang dibagun, sekolah akan lebih fokus dalam penyeleksian guru serta menyediakan pelatihan untuk pengembangan skill para guru.

Bagan alur penelitian ditunjukkan melalui bagan Fishbone sebagai berikut :

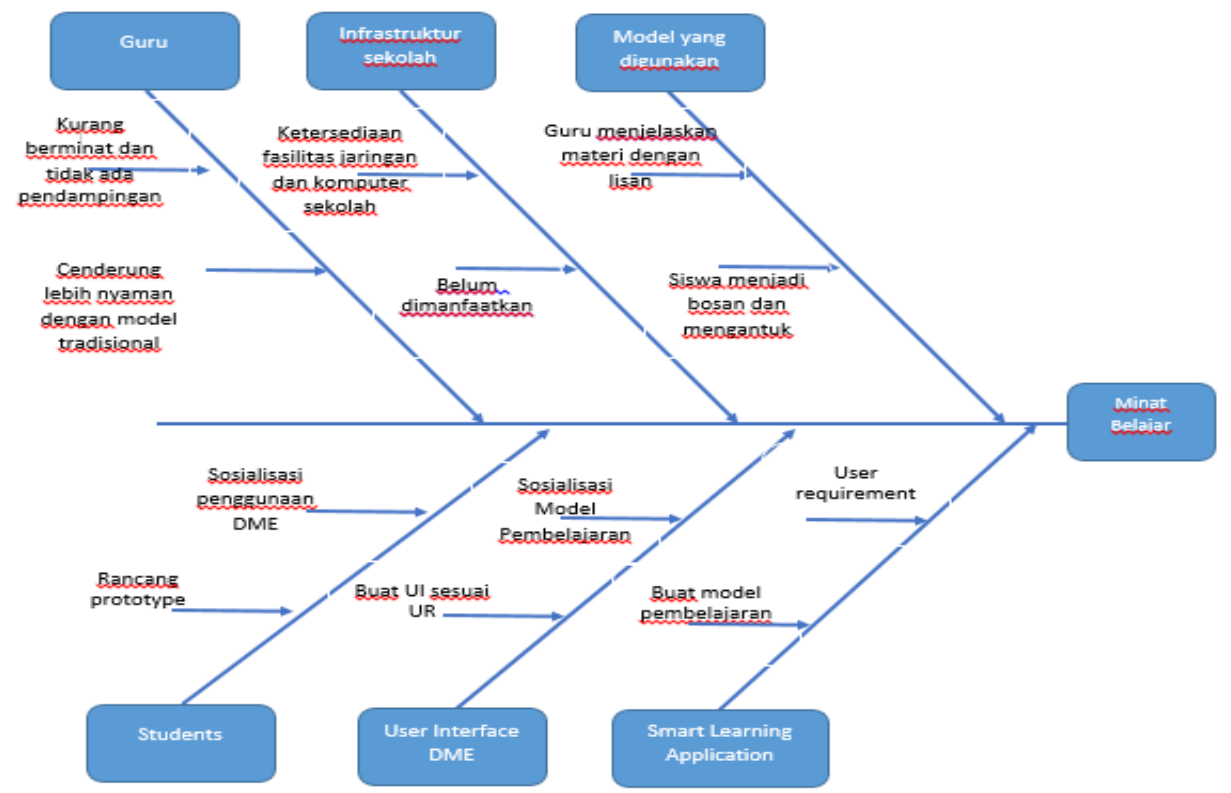

Gambar 2. fishbone diagram 


\subsection{Jenis Penelitian}

Jenis penelitian ini bersifat verifikatif karena penelitian dilakukan untuk mendeskripsikan nilai variabel-variabel penelitian serta memastikan adanya hubungan dan pengaruh antara variabel independen terhadap variabel dependen. Study setting yang digunakan adalah studi lapangan karena pengambilan data melalui penyebaran kuesioner yang dilakukan satu kali tanpa ada perbandingan (cross-sectional), serta tidak dilakukan manipulasi terhadap variabel bebas (Utarie, 2013).

\subsection{Metode Pengambilan Sampel}

Pengambilan sampel dilakukan di SMA Negeri 8 Kota Tangerang dengan focus kepada siswa kelas 8. Pemilihan kelas 8 dikarenakan para siswa ini sudah mengalami 1 tahun pembelajaran di sekolah dengan system berjalan sehingga dapat lebih objektif dalam mengisi kuisioner yang penulis bagikan. Penentuan jumlah sampel menggunakan probability sampling di mana semua elemen populasi mempunyai peluang yang sama untuk dijadikan sebagai sampel.

Pada sampling ini digunakan Rumus Slovin :

dimana $\quad \mathrm{N}=$ jumlah populasi $=312$

$$
\mathrm{n}=\mathrm{N} /[1+\mathrm{Ne} 2]
$$

$$
\mathrm{e}=\text { margin of error }=10 \%=0,01
$$

Sehingga $\mathrm{n}=312 /[1+312(0,01) 2]=75,728$ dibulatkan menjadi 76 sampel. Kemudian kami bulatkan menjadi 81 responden.

\subsection{Hasil}

Berikut ini merupakan hasil olah data kuisioner :

Tabel 1. Descriptive statistics atas pertayaan tipe 1

\section{Descriptive Statistics}

\begin{tabular}{|l|l|r|r|r|r|}
\hline & $\mathrm{N}$ & Minimum & Maximum & Mean & Std. Deviation \\
\hline QT1.1 & 81 & 1 & 2 & 1.33 & .474 \\
QT1.2 & 81 & 1 & 2 & 1.79 & .410 \\
QT1.3 & 81 & 1 & 2 & 1.14 & .345 \\
QT1.4 & 81 & 1 & 2 & 1.12 & .331 \\
QT1.5 & 81 & 1 & 2 & 1.11 & .316 \\
QT1.6 & 81 & 1 & 2 & 1.22 & .418 \\
QT1.7 & 81 & 1 & 2 & 1.31 & .465 \\
QT1.8 & 81 & 1 & 2 & 1.27 & .448 \\
QT1.9 & 81 & 1 & 2 & 1.33 & .474 \\
QT1.10 & 81 & 1 & 2 & 1.41 & .494 \\
Valid N (listwise) & 81 & & & & \\
\hline
\end{tabular}

Berdasarkan nilai mean rata-rata pada table 1, sebagian besar siswa sudah mengethui informasi terkait sekolah mulai dari update informasi seputar kegiatan sekolah, fasilitas maupun infrastruktur. Dan hal ini menjadi alasan kenapa siswa menginginkan model pembelajaran yang lebih inovatif yang sebenarnya ternyata sudah mereka mulai di IT Club sebagai salah satu kegiatan ekstrakurikuler mereka. 
Tabel 2. Descriptive statistics atas pertanyaan tipe 2

\begin{tabular}{|l|r|r|r|r|r|}
\hline \multicolumn{7}{|c|}{ Descriptive Statistics } \\
\hline & $\mathrm{N}$ & Minimum & Maximum & Mean & Std. Deviation \\
\hline QT2.1 & 81 & 1 & 2 & 1.43 & .498 \\
\hline QT2.2 & 81 & 1 & 2 & 1.20 & .401 \\
\hline QT2.3 & 81 & 1 & 2 & 1.17 & .380 \\
\hline QT2.4 & 81 & 1 & 2 & 1.07 & .264 \\
\hline QT2.5 & 81 & 1 & 2 & 1.10 & .300 \\
\hline QT2.6 & 81 & 1 & 2 & 1.15 & .357 \\
\hline QT2.7 & 81 & 1 & 2 & 1.20 & .401 \\
\hline QT2.8 & 81 & 1 & 2 & 1.10 & .300 \\
\hline QT2.9 & 81 & 1 & 2 & 1.14 & .345 \\
\hline QT2.10 & 81 & 1 & 2 & 1.12 & .331 \\
\hline QT2.11 & 81 & 1 & 2 & 1.14 & .345 \\
\hline QT2.12 & 81 & 1 & 2 & 1.09 & .283 \\
\hline Valid N (listwise) & 81 & & & & \\
\hline
\end{tabular}

Lebih dari 90\% siswa menginginkan suasana belajar yang lebih inovatif dibandingkan hanya pembelajaran satu arah dari guru dan dikombinasikan dengan diskusi antara guru dengan siswa. Lebih dari $90 \%$ siswa menginginkan suasana belajar yang lebih inovatif dibandingkan hanya pembelajaran satu arah dari guru dan dikombinasikan dengan diskusi antara guru dengan siswa. 96\% siswa sangat bersemangat untuk mengadobsi pembelajaran dengan e-learning. Siswa tertarik untuk membantu sekolah dalam menyediakan fasilitas tersebut.

Dan berdasarkan nilai mean rata-rata pada tabel 2, siswa sangat jenuh dengan model pembelajaran saat ini sehingga kurang memotivasi siswa untuk belajar lebih giat, kecenderungan yang ada siswa akan memilih lebih banyak belajar berkelompok di jam sekolah dan memotivasi diri dengan sumber belajar lainnya.

\begin{tabular}{|l|r|r|r|r|r|}
\hline \multicolumn{7}{|c|}{ Descriptive Statistics } \\
\hline & $\mathrm{N}$ & Minimum & Maximum & Mean & Std. Deviation \\
\hline QT3.1 & 81 & 1 & 3 & 2.37 & .679 \\
\hline QT3.2 & 81 & 1 & 3 & 1.63 & .558 \\
\hline QT3.3 & 81 & 1 & 3 & 1.84 & .486 \\
\hline QT3.4 & 81 & 1 & 3 & 1.81 & .503 \\
\hline QT3.5 & 81 & 1 & 3 & 1.94 & .780 \\
\hline QT3.6 & 81 & 1 & 3 & 1.93 & .628 \\
\hline QT3.7 & 81 & 1 & 3 & 1.91 & .552 \\
\hline QT3.8 & 81 & 1 & 3 & 1.84 & .511 \\
\hline QT3.9 & 81 & 1 & 3 & 1.88 & .620 \\
\hline QT3.10 & 81 & 1 & 3 & 2.43 & .651 \\
\hline QT3.11 & 81 & 1 & 3 & 1.98 & .612 \\
\hline QT3.12 & 81 & 1 & 3 & 2.00 & .632 \\
\hline QT3.13 & 81 & 1 & 3 & 2.04 & .580 \\
\hline QT3.14 & 81 & 1 & 3 & 2.17 & .587 \\
\hline QT3.15 & 81 & 1 & 3 & 2.02 & .547 \\
\hline QT3.16 & 81 & 1 & 3 & 2.09 & .505 \\
\hline QT3.17 & 81 & 1 & 3 & 2.11 & .570 \\
\hline QT3.18 & 81 & 1 & 3 & 2.28 & .506 \\
\hline QT3.19 & 81 & 1 & 3 & 2.16 & .535 \\
\hline
\end{tabular}




\begin{tabular}{|l|l|l|l|l|l|}
\hline QT3.20 & 81 & 1 & 3 & 2.19 & .503 \\
\hline QT3.21 & 81 & 1 & 3 & 2.19 & .527 \\
\hline QT3.22 & 81 & 1 & 3 & 2.17 & .519 \\
\hline QT3.23 & 81 & 1 & 3 & 2.06 & .599 \\
\hline QT3.24 & 81 & 1 & 3 & 2.21 & .518 \\
\hline QT3.25 & 81 & 1 & 3 & 2.21 & .493 \\
\hline QT3.26 & 81 & 1 & 3 & 2.17 & .519 \\
\hline Valid N (listwise) & 81 & & & & \\
\hline
\end{tabular}

Sebagian kecil siswa masih menginginkan system pembelajaran konvensional namun hanya untuk case tertentu. Seperti pembahasan terkait latihan-latihan pembelajaran untuk persiapan ulangan.

Berdasarkan hasil kuisioner, pihak sekolah yang diwakili oleh Guru Bimbingan Konseling dan IT serta salah satu guru mataplejaran melakukan diskusi mendalam terkait fenomena kebutuhan siswa terhadap pengembangan pmodel pembelajaran. Semua materi guru yang sudah dibuat menggunakan slide ppt akan ditampung dalam sebuah wadah berbasis lokal.

\section{KESIMPULAN DAN SARAN}

Hasil penelitian ini memberikan hasil yang sangat membantu pihak sekolah dalam mengembangkan model pembelajaran. Siswa "jaman now" sangat kreatif dan memiliki banyak ide dalam menyerap pembelajaran. Metode manual yang masih sebatas diskusi face to face tanpa adanya alat bantu lain yang memiliki unsur "belajar santai namun berhasil" cenderung membuat siswa akan boring dan kurang memiliki motivasi dalam menyerap materi pembelajaran. Namun karena sekolah ini merupakan salah satu sekolah unggulan maka hal ini tidak terlalu signifikan terlihat dalam prosesnya namun sangat signifikan dari minat dan hasil belajar siswa. Tentu saja hal ini menjadi sebuah referensi positif untuk terus mengembangkan model pembelajaran oleh pihak sekolah melalui para pengajarnya.

Perlu improvisasi lebih lanjut bagi pihak sekolah dalam memfasilitasi guru untuk mengembangkan model-model pembelajaran, seperti training, pelatihan, seminar dan lainnya.

Tahapan selanjutnya adalah merancang prototype yang sebelumnya sudah didiskusikan dengan pihak sekolah dan perwakilan siswa di OSIS. Baik terhadap fitur-fitur yang akan dipublish termasuk model entertaint nya. Siswa sangat tertarik dengan konsep edutainment karena sangat inspiratif, full colour dan warna warninya serta tampilan yang sangat menarik.

\section{DAFTAR PUSTAKA}

A'yun, D.Q., Prihandono, T. and Wahyuni, S., 2012. Penerapan Model Pembelajaran Kooperatif Tipe Stad Berbasis Multimedia Audio Visual Dalam Pembelajaran Fisika Di Smp.

Andikaningrum, L., Damayanti, W. and Dewi, C., 2014. Efektivitas E-Book Berbasis Multimedia Menggunakan Flip Book Maker sebagai Media Pembelajaran dalam Meningkatkan Keaktifan Belajar Siswa (Studi Kasus pada Mata Pelajaran TIK Kelas XI SMA Kristen Satya Wacana Salatiga) (Doctoral dissertation, Program Studi Pendidikan Teknologi Informasi dan Komunikasi FTI-UKSW).

Barokati, N. and Annas, F., 2013. Pengembangan Pembelajaran Berbasis Blended Learning pada Mata Kuliah Pemrograman Komputer (Studi Kasus: UNISDA Lamongan). SISFO Vol 4 No 5,4 .

Bonus, J.A. and Mares, M.L., 2018. When the Sun Sings Science, Are Children Left in the Dark? Representations of Science in Children's Television and Their Effects on Children's Learning. Human Communication Research, 44(4), pp.449-472. 
Diartono, D.A., 2008. Media Pembelajaran Desain Grafis Menggunakan Photoshop Berbasis Multimedia. Dinamik-Jurnal Teknologi Informasi, 13(2).

Hanum, N.S., 2013. Keefetifan E-Learning sebagai Media Pembelajaran (Studi Evaluasi Model Pembelajaran E-Learning SMK Telkom Sandhy Putra Purwokerto). Jurnal Pendidikan Vokasi, 3(1).

Hariri, A., \& Fihri, H. (2014). Using documentaries for designing elearning activities. Procedia Social and Behavioral Sciences, 116, 2752-2756. https://doi.org/10.1016/j.sbspro.2014.01.649

Hubackova, S. (2014). Pedagogical Foundation Of Elearning. Procedia - Social and Behavioral Sciences, 131(2004), 24-28. https://doi.org/10.1016/j.sbspro.2014.04.073

Novaliendry, D., 2013. Aplikasi game geografi berbasis multimedia interaktif (studi kasus siswa kelas IX SMPN 1 RAO). Jurnal Teknologi Informasi \& Pendidikan, 6(2), pp.106-118.

Peebles, A., Bonus, J.A. and Mares, M.L., 2018. Questions+ answers+ agency: Interactive touchscreens and Children's learning from a socio-emotional TV story. Computers in Human Behavior, 85, pp.339-348.

Priyanto, D., 2009. Pengembangan Multimedia Pembelajaran Berbasis Komputer. Insania, 14(1), pp.92-110.

Popovici, A., \& Mironov, C. (2015). Students perception on using eLearning technologies. Procedia - Social and Behavioral Sciences, 180(November 2014), 1514-1519. https://doi.org/10.1016/j.sbspro.2015.02.300

Vebrianto, R. and Osman, K., 2011. The effect of multiple media instruction in improving students' science process skill and achievement. Procedia-Social and Behavioral Sciences, 15, pp.346350.

Weng, C., Otanga, S., Weng, A. and Cox, J., 2018. Effects of interactivity in E-textbooks on 7th graders science learning and cognitive load. Computers \& Education, 120, pp.172-184.

Zulaeha, I., 2013. Innovation Models of Indonesian Learning in Multicultural Society. ProcediaSocial and Behavioral Sciences, 103, pp.506-514. 